\title{
Rhizobacterium and acibenzolar-S-methyl (ASM) in resistance induction against bacterial blight and expression of defense responses in cotton
}

\author{
Alessandra K.N. Ishida ${ }^{1 *}$, Ricardo M. Souza ${ }^{1}$, Mário Lúcio V. Resende ${ }^{1}$, Fábio R. Cavalcanti², Dili L. \\ Oliveira $^{1}$ \& Edson A. Pozza ${ }^{1}$
}

${ }^{1}$ Departamento de Fitopatologia, Universidade Federal de Lavras, Cx. Postal 3037, 37200-000, Lavras, MG, Brazil; ${ }^{2}$ Universidade Federal do Piauí, Campus Cinobelina Elvas, 64900-000, Bom Jesus, PI, Brazil

Corresponding author: Alessandra K.N. Ishida, e-mail: keiko@cpatu.embapa.br

\begin{abstract}
The effect of acibenzolar-S-methyl (ASM) and the rhizobacterium isolate L2-1 (Bacillus cereus), applied either alone or in combination, was evaluated in cotton plants for resistance induction against Xanthomonas axonopodis pv. malvacearum. Bacterial blight severity, lignin content and the activities of phenylalanine ammonia-lyase (PAL), peroxidase (POX) and $\beta-1.3$ glucanase (GLU) were assessed at different time courses. ASM and L2-1, used alone or in combination, significantly reduced disease severity, while ASM alone was the best treatment for bacterial blight control. No synergistic effect was observed when ASM was associated to isolate L2-1. ASM induced the highest increases in the activities of PAL, POX and GLU as well as lignin deposition, mainly 14 days after treatment application. When ASM and the rhizobacterium were simultaneously applied, enzyme activities were always lower, compared to ASM alone.
\end{abstract}

Keywords: Gossypium hirsutum, Xanthomonas axonopodis pv. malvacearum, induced resistance.

RESUMO

Rizobactéria e Acibenzolar-S-Metil (ASM) na indução de resistência à mancha angular e na expressão de respostas de defesa em algodoeiro

$\mathrm{O}$ efeito do acibenzolar-S-metil (ASM) e do isolado rizobacteriano L2-1 (Bacillus cereus), aplicados isoladamente ou simultaneamente, foi avaliado em plantas de algodão na indução de resistência contra Xanthomonas axonopodis pv. malvacearum. A severidade da mancha angular, o conteúdo de lignina e a atividade das enzimas fenilalanina amônia liase, peroxidase e $\beta$-1,3-glucanase foram avaliados periodicamente. O ASM e o isolado L2-1, utilizados isolada ou simultaneamente, reduziram significativamente a severidade da doença, sendo o ASM, o melhor tratamento para o controle da mancha angular. Não houve efeito sinergístico quando se utilizou o ASM simultaneamente com o isolado L2-1. O ASM proporcionou os maiores aumentos nas atividades das enzimas fenilalanina amônia liase, peroxidase e $\beta$-1,3-glucanase e na deposição de lignina, principalmente aos 14 dias após a aplicação dos tratamentos. Quando o ASM e a rizobactéria foram aplicados simultaneamente, a atividade das enzimas foi sempre inferior ao tratamento em que o ASM foi aplicado isoladamente.

Palavras-chave: Gossypium hirsutum, Xanthomonas axonopodis pv. malvacearum, resistência induzida.

\section{INTRODUCTION}

Bacterial blight, caused by Xanthomonas axonopodis pv. malvacearum (Smith) Vauterin, Hoste, Kersters \& Swings (Xam), is common in major cotton producing regions. In the state of Mato Grosso, Brazil, the disease has increased quite substantially due to the wide dissemination of the pathogen and its high variability, added to the use

Part of the Doctoral Thesis of the first author. Universidade Federal de Lavras, Lavras MG. 2004.

*Present Address: Embrapa Amazônia Oriental, Cx. Postal 48, 66095-100, Belém, PA, Brazil. of susceptible varieties, making its control more difficult (Cassetari Neto \& Machado, 2005).

Research with induced resistance has highlighted the essential role of some microorganisms, natural and/or chemical products in activating expression of defense genes. Although relatively rare, examples of use of rhizobacteria and chemical products for resistance induction and control of plant diseases have been registered in the literature (van Loon et al., 1998; van Wees et al., 2000; Baysal et al., 2003; Silva et al., 2004; Halfeld-Vieira et al., 2006; Cavalcanti et al., 2007).

In incompatible interactions, systemic acquired resistance (SAR) is associated with the hypersensitive reaction (HR) and is characterized by the initial increment of endogenously synthetized salicylic acid (SA) and late 
activation of PR protein genes (Pieterse et al., 1996; van Loon, 1997). SAR can be induced by pathogens and several chemicals. Among them, acibenzolar-S-methyl (ASM) is the best studied resistance inducer and the first product commercially available as such (Venâncio et al., 2000). This product is systemically translocated in plants on a SAR signaling pathway, inducing the same resistance spectrum and the same group of genes related to defense as SA (Oostendorp et al., 2001). The increase of enzyme activity involved in defense response in plants treated with ASM has been reported (Colson-Hanks \& Deverall, 2000; Baysal et al., 2003; Cavalcanti et al., 2007).

Another form of induced resistance by certain isolates of bacteria from the rhizosphere is called induced systemic resistance (ISR) (van Loon et al., 1998). ISR has been demonstrated in beans, carnation, cucumber, radish, tobacco, tomato and in the model plant Arabidopsis thaliana, and has been effective against a wide spectrum of plant pathogens, including fungi, bacteria and viruses (van Loon et al.,1998). Studies have demonstrated that ISR is independent of the accumulation of SA and activation of PR genes, unlike SAR (Pieterse et al., 1996). Furthermore, the signal transduction which leads to ISR requires response to jasmonic acid and to ethylene and, similarly to SAR, is dependent on NPR1 protein (Pieterse et al., 1998). Van Wees et al. (2000) investigated possible interactions between SAR mediated by DC3000 avirulent isolate of Pseudomonas syringae pv. tomato (Okabe) Young, Dye \& Wilkie and ISR mediated by WCS417r isolate of P. fluorescens (Migula, 1895). Curiously, the simultaneous activation of these pathways resulted in an additive effect in induced resistance level against $P$. syringae pv. tomato. Despite the progress in understanding the mechanisms involved in ISR, the induction mechanism is not well understood and the markers have not yet been identified. However, the increase in phenylalanine ammonia-lyase, peroxidase, polyphenol oxidase and lipoxigenase activities has been demonstrated in tomato and cucumber plants and on Festuca arundinacea after treatment with growth inducing rhizobacteria (Chen et al., 2000; Kilic-Ekici \& Yuen, 2004; Silva et al., 2004; Lavania et al., 2006; Saravanakumar et al., 2007).

The objectives of this work were to evaluate the effects of the rhizobacterium strain L2-1 Bacillus cereus Frankland and Frankland and ASM, alone or in combination, on bacterial blight symptom reduction and on the total lignin content on leaves, and to determine the activity of phenylalanine ammonia-lyase (PAL), peroxidase (POX) and $\beta-1.3$ glucanase, which are possibly involved in the defense responses of cotton plants to Xam.

\section{MATERIAL AND METHODS}

\section{Plant material}

Under greenhouse conditions, seeds of susceptible cotton cultivar CNPA Ita 90 were previously desinfested for 5 minutes with sodium hypochlorite at $1 \%$ and seeded in $1.5 \mathrm{~kg}$ capacity pots containing a mixture of soil, sand and manure $(2: 1: 1)$ that had been previously fumigated with methyl bromide.

\section{Bacterial isolates and inoculation}

Xam isolate used in the assays was obtained from cotton leaves collected in Rondonópolis, MT, Brazil, with typical bacterial blight lesions. This isolate was preserved in peptone glycerol at $-80{ }^{\circ} \mathrm{C}$ and on dried infected leaves. Isolation was made in 523 medium (Kado \& Heskett, 1970 ) by the streaking method. Pathogen inoculation was carried out 28 days after seedling emergence, spraying the lower surface of the leaves with a bacterial suspension at $10^{9} \mathrm{UFC} / \mathrm{mL}$. Plants were kept 24 hours before and after inoculation in a humidity chamber and placed in a greenhouse under average temperature of $32^{\circ} \mathrm{C}$ and automatic irrigation. The rhizobacterium strain L21 Bacillus cereus, previously selected since it reduced bacterial blight symptoms (Ishida, 2004), was obtained from the rhizosphere of cotton plants in Lavras, Minas Gerais, Brazil and preserved in glycerol peptone at $80^{\circ} \mathrm{C}$. For experimental use, the rhizobacterium was transferred to the 523 medium by the streaking method and incubated for $48 \mathrm{~h}$ at $28^{\circ} \mathrm{C}$. For preparation of the bacterial suspension, colonies of L2-1 isolate were diluted in sterile tap water, and the concentration adjusted to $\mathrm{A}_{600}$ $=0.50$. Inoculation was made by soil irrigation $(1.5 \mathrm{Kg}$ capacity pots) with $100 \mathrm{~mL}$ of bacterial suspension.

\section{Effect of ASM and the rhizobacterium strain L2-1 on cotton bacterial blight severity}

The following treatments were used to evaluate the effect of ASM and L2-1 isolate in bacterial blight severity: 1. application of ASM; 2. application of L2-1 isolate; 3 . application of ASM and L2-1 isolate; 4. inoculated control; 5) absolute control (not treated and not inoculated).

An aqueous solution of ASM was used with 10 $\mathrm{g}$ of active ingredient/100 L of water, spraying leaves until dripping. All treatments were applied 7 days before inoculation with Xam. Severity of bacterial blight was evaluated at 7, 14, 21, 28 and 35 days after inoculation with the pathogen, using an adaptation of the scale of Sidhu and Webster (1977), which is based on mark criteria varying from 0 to 4 , where $0=0 \%$ of leaf area with lesions; $1=$ 1 to $25 \%$ of leaf area with lesions; $2=26$ to $50 \%$ of leaf area with lesions; $3=51$ to $75 \%$ of leaf area with lesions; $4=$ over $76 \%$ of leaf area with lesions. For calculations of the area under disease progress curve (AUDPC), the following formula was used: AUDPC $=\sum\left(\left(\mathrm{Y}_{\mathrm{i}}+\mathrm{Y}_{\mathrm{i}+1}\right)\right.$ / 2) $\left.\left(\mathrm{t}_{\mathrm{i}+1} \mathrm{t}_{\mathrm{i}}\right)\right)$, where $Y$ represents disease intensity, $t$ the time and $i$ the number of field evaluations (Shaner \& Finney, 1977). The analysis of variance was calculated and mean comparisons made by Tukey's multiple range test at 5\% of probability. The experiments followed randomized complete block design with 5 treatments and 4 replicates (6 plants/replicate). 


\section{Determining activity of defense enzymes in cotton plants}

The following treatments were used for assessing the activities of phenylalanine ammonia-lyase (PAL), peroxidase (POX) and $\beta$-1.3-glucanase and the accumulation of lignin: 1. application of ASM followed by pathogen inoculation; 2. application of ASM with no pathogen inoculation; 3. application of rhizobacteria followed by pathogen inoculation; 4. application of rhizobacteria with no pathogen inoculation; 5. application of rhizobacteria and ASM followed by pathogen inoculation; 6. application of rhizobacteria and ASM with no pathogen inoculation; 7. pathogen inoculation with no application of either ASM or rhizobacteria; 8. absolute control.

All treatments were applied 7 days in advance of Xam inoculation in greenhouse. The statistical design was the completely randomized blocks with 8 treatments and 4 replicates (6 plants/replicate). The analysis of variance was carried for each variable and means compared by Tukey's multiple range test at $5 \%$ of probability.

\section{Plant extract and determination of total protein content}

Leaf samples for enzyme extraction were collected 3 and 7 days after treatment applications and 3 and 7 days after pathogen inoculation for all treatments. Each sample was placed in a duly identified plastic bag, frozen in liquid nitrogen and stored at $-80^{\circ} \mathrm{C}$. For preparation of plant extracts, each frozen sample was individually ground in liquid nitrogen and homogenized in $50 \mathrm{mM}$, pH 5.2 sodium acetate buffer, $1 \mathrm{~g}$ of fresh material to $3 \mathrm{~mL}$ of buffer, for 10 minutes. The homogenized extract was centrifuged at 14,000 $\mathrm{x} g$ for 20 minutes and the supernatant transferred to plastic tubes and stored at $-80^{\circ} \mathrm{C}$ for later analysis. The total protein concentration was determined using bovine serum albumin (BSA) as a standard, according to Bradford (1976).

\section{Phenylalanine ammonia-lyase (PAL) (EC. 4.3.1.5)}

For PAL analysis, $100 \mu \mathrm{L}$ of plant extract $+50 \mu \mathrm{L}$ of L-phenylalanine $(6 \mu \mathrm{M})+850 \mu \mathrm{L}$ of Tris- $\mathrm{HCl} 50 \mathrm{mM}, \mathrm{pH}$ 8.4 buffer solution were used. The reactive mix was placed in a double boiler at $37^{\circ} \mathrm{C}$ for 70 minutes. After this period, $50 \mu \mathrm{L}$ of chloridic acid $50 \mathrm{~N}$ was added to stop reaction. The amount of trans-cinnamic acid formed by phenylalanine was measured on a spectrophotometer $(\lambda=290 \mathrm{~nm})$. For comparison purposes, PAL of Rhodotorula glutinis (Fresen.) F.C. Harrison 1928 (Sigma, St. Louis, MO, USA) was used, and the result expressed as PAL activity unit (pKat) per mg of protein contained in each sample (Beaudoin-Eagan \& Thorpe, 1985).

\section{$\beta$-1.3-glucanase (EC. 3.2.1.6)}

$\beta$-1.3-glucanase activity was determined according to the methodology described by Xue et al. (1998). The reacting mixture containing $50 \mu \mathrm{L}$ of extraction buffer, 200 $\mu \mathrm{L}$ of plant extract and $250 \mu \mathrm{L}$ of laminarine $(4.0 \mathrm{mg} / \mathrm{mL})$ was incubated at $60^{\circ} \mathrm{C}$ for 1 hour. A solution containing copper sulphate and sodium and potassium tartrate was added as follows. The mixture was heated to $100^{\circ} \mathrm{C}$ for 20 minutes to stop the hydrolytic activity. Absorbance at 520 $\mathrm{nm}$ was determined after sample cooling and the result expressed as $\beta$-1.3-glucanase (nKat) activity unit per mg of protein contained in each sample.

\section{Peroxidase (POX) (EC. 1.11.1.7)}

Peroxidase activity was determined by the addition of $25 \mu \mathrm{L}$ of plant extract to $2 \mathrm{~mL}$ of a solution containing

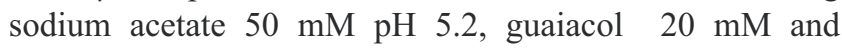
hydrogen peroxide $20 \mathrm{mM}$. Absorbance was measured at $480 \mathrm{~nm}$ (Urbanek et al., 1991) after incubation at $30^{\circ} \mathrm{C}$ for $10 \mathrm{~min}$ and the result expressed as peroxidase activity (UA) per $\mathrm{mg}$ of protein contained in each sample.

\section{Lignin}

Samples were collected for all treatments 7 days after the inoculation with the pathogen (14 days after applying treatments). Each sample was placed in plastic bags, frozen in liquid nitrogen and stored in freezer at $80^{\circ} \mathrm{C}$. For determination of the lignin content, $0.2 \mathrm{~g}$ of each sample was macerated with liquid nitrogen and incubated in acetone for $24 \mathrm{~h}$. The material was dried for $48 \mathrm{~h}$ at $60^{\circ} \mathrm{C}$ and homogenized. A mixture of thioglycolic acid and chloridic acid $2 \mathrm{~N}(1: 10)$ was added to the homogenized tissue samples $\left(5 \mathrm{~mL}\right.$ of the mix to $15 \mathrm{mg}$ of tissues) for $4 \mathrm{~h}$ at $100^{\circ} \mathrm{C}$, and washed with water; the lignothioglycolic acid was extracted from the precipitate with $5 \mathrm{~mL}$ sodium hidroxide $(\mathrm{NaOH}$ $0.5 \mathrm{~N}$ ) for $18 \mathrm{~h}$. The samples were then centrifuged at 8.000 $\mathrm{x} g$ for 15 minutes, acidified with concentrated $\mathrm{HCl}$ and incubated at $4^{\circ} \mathrm{C}$ for $4 \mathrm{~h}$, followed by new centrifugation and ressuspension of the precipitate in $\mathrm{NaOH} 0.5 \mathrm{~N}$. The absorbance of thioglycolic acid (TGA) derivatives was determined at $280_{\mathrm{nm}}$ (Monties, 1989). The statistical design was randomized complete blocks, with 8 treatments and 4 replicates (6 plants/replicate). The analysis of variance was done and means compared by the Scott Knott test at 5\% of probability.

\section{RESULTS AND DISCUSSION}

Effect of ASM and the L2-1 rhizobacterium strain of Bacillus cereus on the severity of cotton bacterial blight

All treatments were statistically different from the inoculated control (Table 1). The treatment with ASM caused a major reduction in bacterial blight disease, with $57.81 \%$ of disease reduction as compared to the control, statistically different from plants treated with the L2-1 isolate, which showed $25.48 \%$ of control. On tomato plants, Cavalcanti et al. (2007) obtained $49.3 \%$ of protection against Xanthomonas vesicatoria (ex Doidge 1920) Vauterin, Hoste, Kersters \& Swings with ASM treatment. In studies where the rhizobacteria-mediated ISR and pathogen induced SAR were directly compared, the level of disease suppression was similar. In radish, Hoffland et al. (1996) verified that 
TABLE 1 - Effect of acibenzolar-S-methyl and rhizobacterium strain L2-1 of Bacillus cereus, applied alone or together, on severity of bacterial blight caused by Xanthomonas axonopodis pv. malvacearum measured by the area under the disease progress curve - AUDPC

\begin{tabular}{lrcc}
\hline \hline Treatments & AUDPC & $\begin{array}{c}\text { Percentage of control } \\
\text { in relation to the } \\
\text { inoculated control }\end{array}$ \\
\hline Absolute control & 0 & $\mathrm{a}^{1}$ & - \\
Acibenzolar-S-metil (ASM) & 54.65 & $\mathrm{~b}$ & 57.81 \\
ASM + L2-1 Isolate & 66.37 & $\mathrm{bc}$ & 48.76 \\
L2-1 Isolate & 96.53 & $\mathrm{c}$ & 25.48 \\
Inoculated Control & 129.53 & $\mathrm{~d}$ & - \\
CV (\%) & 19.58 & & \\
\hline
\end{tabular}

${ }^{1}$ Means followed by the same letter do not differ by Tukey's multiple range test at $5 \%$ of probability.

resistance induced by the WCS417 isolate of $P$. fluorescens (ISR) was similar to that induced by $P$. syringae pv. tomato avirulent isolate (SAR).

The treatment ASM + L2-1 isolate applied simultaneously was not statistically different from ASM treatment and L2-1 isolate applied separately, but it gave a lower level of protection when compared to ASM and a higher level of protection to the L2-1 isolate, with $48.76 \%$ of control when compared with the control treatment (Table 1). These results are comparable to those found by Traw et al. (2003), where the simultaneous application of salicylic acid and jasmonic acid had a negative effect on growth reduction of $P$. syringae pv. tomato on Arabidopsis thaliana plants but differed from those found by Van Wees et al. (2000), where the simultaneous activation of SAR and ISR resulted in an additive effect on the induced protection level against the DC3000 isolate of $P$. syringae pv. tomato. Studies have demonstrated that signal transduction which carries ISR requires a response from jasmonic acid and from ethylene, yet some Bacillus isolates require salicylic acid and not jasmonic acid to induce resistance on Arabidopsis thaliana (Ryu et al., 2003).

\section{Defense enzyme activities in cotton plants : \\ Phenylalanine ammonia-lyase (PAL)}

Plants treated with ASM and rhizobacterium L2-1 (Figure 1a, b) only had the highest PAL activities 14 days after application of treatments. PAL activity was high in all treatments, except for the absolute control (Figure 1b). Chen et al. (2000) observed that cucumber plants treated with isolates 13 of Pseudomonas corrugata (Roberts \& Scarlett 1981) and 63-28 of P. aureofaciens (Kluyver, 1956) presented higher activity of this enzyme two days after treatment application.

Among the treatments analyzed, PAL activity varied from $0.065 \mathrm{pKat} / \mathrm{mgP}$ in the simultaneous treatment with ASM and the application of rhizobacteria seven days later, to $3.657 \mathrm{pKat} / \mathrm{mgP}$ in the treatment with ASM on inoculated plants, 14 days after treatment application (Figure 1a, b). In almost all treatments, PAL activity was higher seven days after pathogen inoculation (14 days after treatment application), except for plants not inoculated and simultaneously treated with ASM and the rhizobacterium (Figure 1b). PAL activity in this treatment was always lower than in those where ASM and rhizobacteria alone were applied. PAL leads to lignin precursors and several secondary plant metabolites, derived from phenylpropanoid pathways involved in resistance, like phytoalexins and salicylic acid (SA) and is induced in many defense reactions. In general, pathogen inoculation increased PAL activity in treatments, except on plants treated with rhizobacterium, when non-inoculated plants showed higher activity than inoculated ones. Similar results were observed by Chen et al. (2000), when cucumber plants treated with isolates 13 of $P$. corrugata and 63-28 of P. aureofaciens had
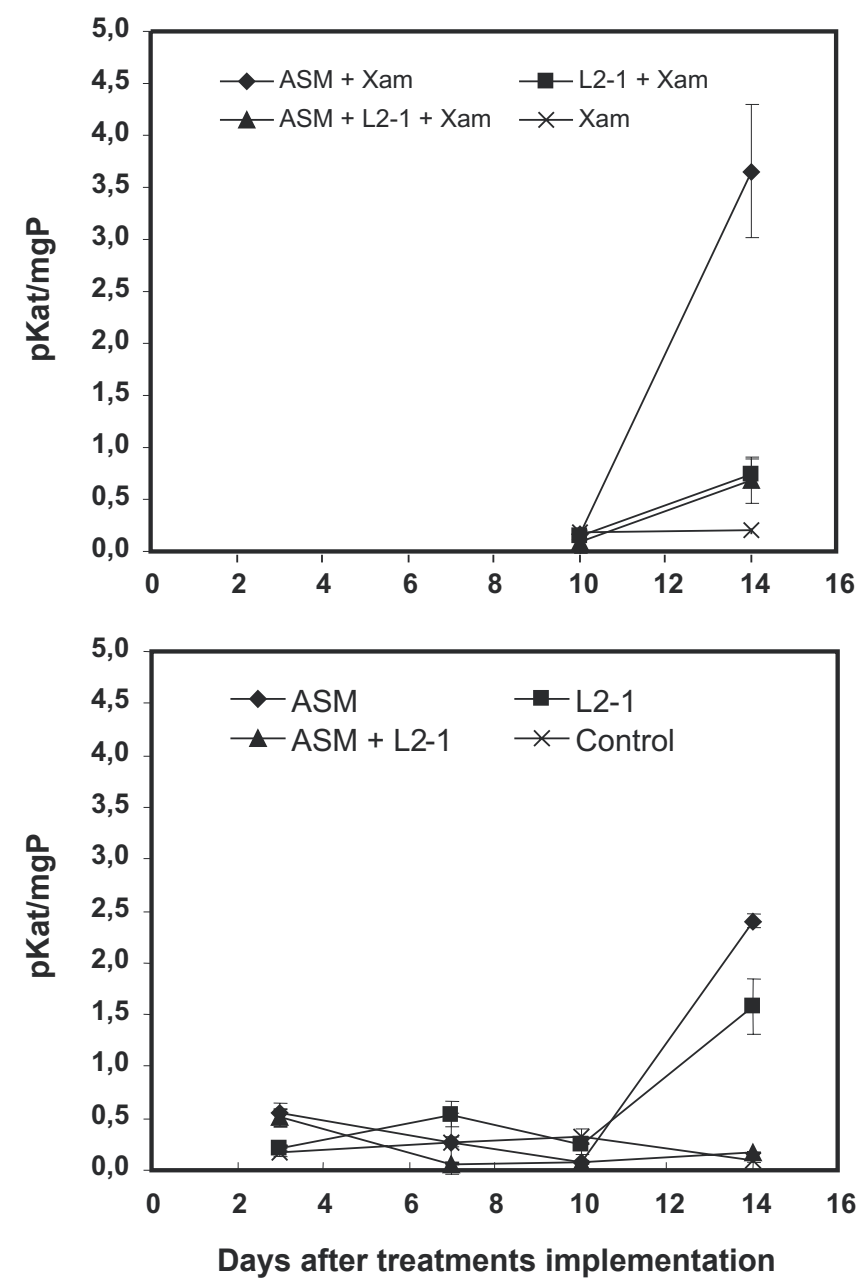

FIG. 1 - Phenylalanine ammonia-lyase (PAL) activity determined in cotton plants submitted to the following treatments: acibenzolarS-methyl (ASM), isolate L2-1 of Bacillus cereus, ASM + L2-1 and control followed (a) or not (b) by inoculation of Xanthomonas axonopodis pv. malvacearum (Xam). Bars represent standard deviations.

Tropical Plant Pathology 33 (1) January - February 2008 
high levels of PAL activity at the beginning but no increase in activity was observed when inoculated with Pythium aphanidermatum. Silva et al. (2004) observed that tomato seed microbiolization with rhizobacteria increased PAL activity, and that no alterations were observed in enzyme activity in relation to control after pathogen inoculation. However, the expression of certain inducible genes to ethylene and jasmonic acid in plants of Arabidopsis is significantly increased in leaves expressing ISR after inoculation with Pst DC3000 when compared to control plants, suggesting that, in Arabidopsis, ISR is associated with activation of a specific group of genes that can be induced by jasmonic acid (AJ) (Pieterse et al., 2004). Activation of genes related to defense leads to a faster and/or higher level of expression after inoculation, with the challenger arising as one common characteristic of different types of induced resistance (Pieterse et al., 2004). According to Lavania et al. (2006), inoculation of Phytophthora nicotianae on untreated pepper plants (Piper betle), reduced PAL activity by $20 \%$ on leaves and roots; nevertheless, the activity of this enzyme increased the presence of the NBRI1213 isolate of Serratia marcescens (Bizio, 1823) on non-inoculated and on plants inoculated with the pathogen.

\section{B-1.3-Glucanase}

After seven days of pathogen inoculation, there was an increase in $\beta-1.3$-glucanase activity on all treated plants, except on the control (Figure 2). Treated and inoculated plants with the pathogen had lower $\beta$ 1.3-glucanase activity than the non-inoculated ones. According to Halfeld-Vieira et al. (2006), the use of a biocontrol agent of the phylloplane (UFV-IEA) on tomato plants did not affect $\beta$-1.3-glucanase, even in plants inoculated with Pst. Nevertheless, on Camellia sinensis plants, treatment with the Pf1 isolate of Pseudomonas fluorescens increased B-1.3-glucanase activity in relation to untreated plants (Saravanakumar et al., 2007).

Plants treated with ASM showed maximum ß-1.3glucanase activity after 14 days of treatment applications (Figures 2a, b). Colson-Hanks \& Deverall (2000) reported high activity of $\beta-1.3$-glucanases five days after application of ASM on cotton. For plants treated with L2-1, a peak was observed seven days after application, and increased again at 14 days. In simultaneous use of ASM and the rhizobacterium, the maximum activity was observed on the seventh day, decreased by the tenth day and increased again 14 days after treatment application (Figure 2b).

Studies with Arabidopsis demonstrated that, contrarily to SAR induced by pathogens, ISR mediated by the WCS417r isolate of P. fluorescens is independent of the activation of PR protein genes (Pieterse et al., 1996). However, it was observed in this work that the rhizobacterium treatment increased B-1.3-glucanase 7 and 14 days after treatment application, statistically different from the control (Figure 2b).
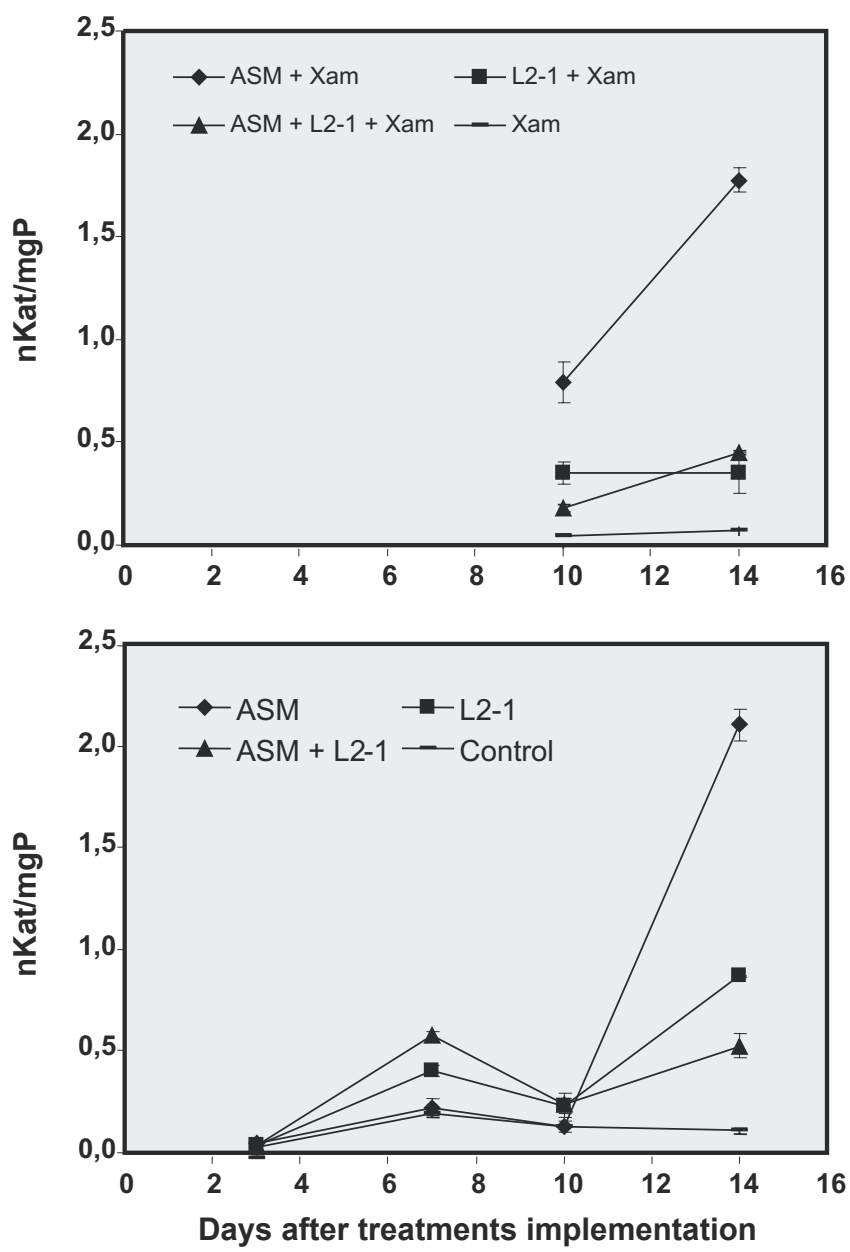

FIG. 2 - - 1.3 -glucanase activity determined in cotton plants submitted to the following treatments: acibenzolar-S-methyl (ASM), isolate L2-1 of Bacillus cereus, ASM + L2-1 and control followed (a) or not (b) by Xanthomonas axonopodis pv. malvacearum (Xam) inoculation. Bars represent standard deviations.

\section{Peroxidase (POX)}

In general, treatments with ASM applied alone showed the highest peroxidase activities, varying from 223.737 to $583.917 \mathrm{mgP} / \mathrm{min}$, with maximum activity after 3 days from application (Figure 3b). In plants of F. arundinacea, the highest peroxidase activity was detected five days after application of ASM (Kilic-Ekici \& Yuen, 2004).

Baysal et al. (2003) observed that tomato plants treated with ASM and inoculated after three days with Clavibacter michiganensis subsp. michiganensis (Smith 1910) Davis et al. $1984(\mathrm{Cmm})$ showed peroxidase activities significantly higher than in the other three treatments (ASM, water + $\mathrm{Cmm}$, and water). Peroxidase activity was approximately three times higher in tomato leaves treated with ASM than in non inoculated control plants five days after the inoculation of the pathogen (Baysal et al., 2003). Tomato plants treated with ASM and those not inoculated showed peroxidase 

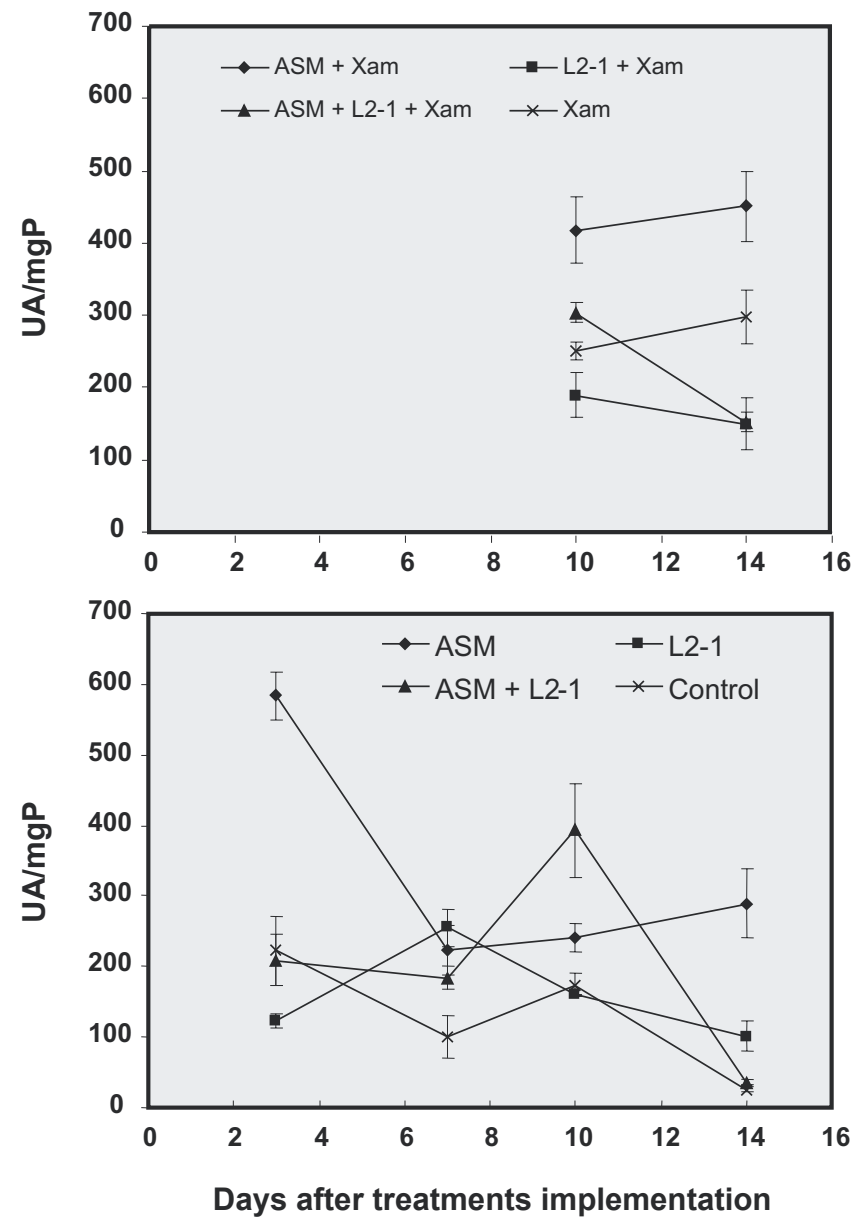

FIG. 3 - Peroxidase activity (POX) determined in cotton plants submitted to the following treatments: acibenzolar-S-methyl(ASM), isolate L2-1 of Bacillus cereus, ASM + L2-1 and control followed (a) or not (b) by Xanthomonas axonopodis pv. malvacearum (Xam) inoculation. Bars represent standard deviations.

activity as high as those treated with ASM and inoculated (Baysal et al., 2003).

The peroxidase activity on treatments with L21 varied between 101,083 and $255,687 \mathrm{mgP} / \mathrm{min}$, with the maximum value observed seven days after the treatment on non-inoculated plants (Figure 3b). In plants of $F$. arundinacea, the increase in peroxidase activity was observed 2 days after application of rhizobacteria (KilicEkici \& Yuen, 2004). Working with cucumber root rot caused by Pythium aphanidermatum, Chen et al. (2000) found an increase in peroxidase activity as the disease progressed, with maximum activity four to six days after pathogen inoculation. Using the split root system, the authors demonstrated the systemic induction of peroxidase by $63-28$ and 13 isolates of Pseudomonas and by P. aphanidermatum. Silva et al. (2004) observed a higher activity of on tomato plants infected with Pseudomonas syringae pv. tomato and originating from seeds microbialized with rhizobacteria in comparison to the other treatments. In the interaction with Pseudomonas syringae pv. tomato, those tomato plants that were treated with Bacillus cereus and inoculated with the pathogen revealed significantly higher levels of peroxidases (PO) than non-treated, inoculated and non-inoculated plants (Halfeld-Vieira et al., 2006). Similar results were found by Lavania et al. (2006), where plants treated with the NBRI1213 isolate of Serratia marcescens and inoculated with Phytophthora nicotianae showed the highest induction levels of this enzyme.

\section{Total lignin content determination}

Seven days after inoculation with Xam, a higher content of lignin was found on plants inoculated and treated with ASM as compared to the other treatments (Figure 4). As for the treatments that were not inoculated, plants treated with L2-1 showed higher TGA-derivate content than the other non-inoculated treatments (Figure 4). The simultaneous application of ASM and rhizobacteria in non-inoculated plants and plants inoculated with the pathogen resulted in lower TGA-derivate content. These results are similar to those obtained for PAL and peroxidase activities, where higher activity was observed on inoculated plants treated with ASM, followed by those treated with the rhizobacterium. The simultaneous application of these two treatments resulted in lower peroxidase activities (Figures 1 and 3). Peroxidases have been related to a variety of processes in plant defense, including hypersensitive reaction, lignification, phenolic and glycoprotein cross-linking on cell wall, suberization and phytoalexin production (Nicholson \& Hammerschimidt, 1992). Thus, it is suggested that the increase in peroxidase activity observed in this study is related to cell wall lignification as a defense response in cotton. Cavalcanti et al. (2007) reported that ASM significantly induced an increase in lignification in tomato plants from 9 to 12 days after its application. According to the authors, inoculation with $X$. vesicatoria did not alter responses of the treatments studied, indicating that, in this case, lignification was not induced solely by bacterial infection. The association between the resistance induced by ASM and the increase of lignin in the cell wall was also observed in other pathosystems (ColsonHanks \& Deverall, 2000; Baysal et al., 2003; Kilic-Ekici \& Yuen, 2004).

It was observed in this work that the simultaneous application of ASM with the L2-1 isolate of Bacillus cereus did not result in increases in enzyme activities and in lignin content, when compared to the application of ASM only. These results are similar to those observed in greenhouse and reported in this work, where plants treated with ASM caused a higher reduction in severity of bacterial blight, statistically different from plants treated with the rhizobacterium, with intermediate values obtained with the simultaneous application of ASM and B. cereus.

Application of ASM increased the activity of the enzymes phenylalanine ammonia-lyase, $\beta$-1.3-glucanase, peroxidase and the content of lignin and also caused a $57.81 \%$ 


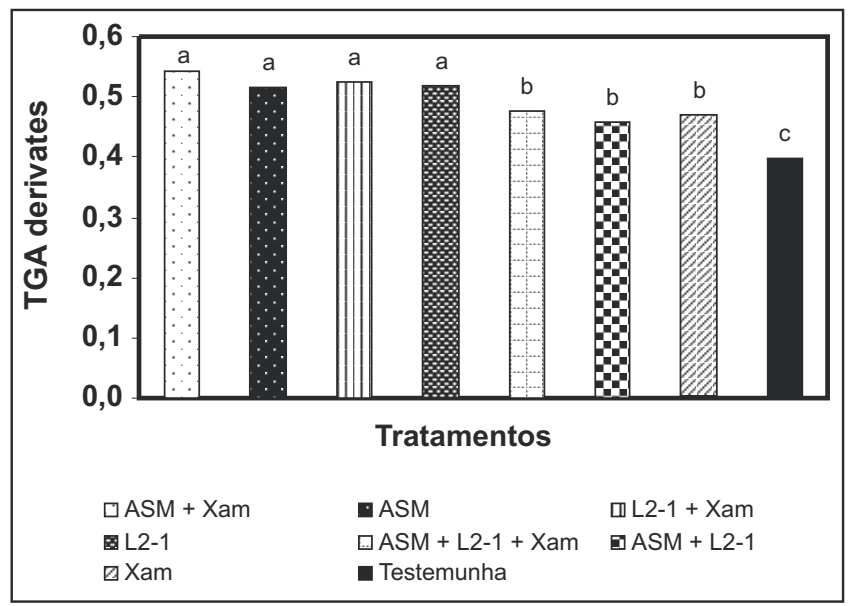

FIG. 4 - Lignin content determination (derived from thioglycolic acid) in cotton 14 days after treating the plants with: acibenzolarS-methyl (ASM), isolate L2-1 of Bacillus cereus, ASM + L2-1, and 7 days after Xanthomonas axonopodis pv. malvacearum (Xam) inoculation. Control $=$ plants not treated and not inoculated. Means followed by the same letter are not statistically different by the Scott Knott test at $5 \%$ probability.

reduction in bacterial blight severity. These results suggest that induced resistance could be a suitable tool for bacterial disease management, although field work is necessary to validate this suggestion.

\section{ACKNOWLEDGEMENTS}

The authors gratefully acknowledge financial support given by Fundação de Amparo à Pesquisa do Estado de Minas Gerais - FAPEMIG (CAG 1081/2002), Conselho Nacional de Desenvolvimento Científico e Tecnológico - CNPq, and Coordenação de Aperfeiçoamento de Pessoal de Nível Superior - CAPES.

\section{REFERENCES}

Baysal O, Soylu EM, Soylu S (2003) Induction of defense-related enzymes and resistance by the plant activator acibenzolar-S-methyl in tomato seedlings against bacterial canker caused by Clavibacter michiganensis subsp. michiganensis. Plant Pathology 52:747-753.

Beaudoin-Eagan LD, Thorpe TA (1985) Tyrosine and phenylalanine ammonia lyase activities during shoot initiation in tobacco callus cultures. Plant Physiology 78:438-441.

Bradford MM (1976) A rapid and sensitive method for the quantification of microgram quantities of proteins utilizing the principle of protein-dye binding. Analytical Biochemistry 72:248254.

Cassetari Neto D, Machado AQ (2005) Doenças do algodoeiro: diagnose e controle. Várzea Grande MT. Universidade de Várzea Grande e Universidade Federal de Mato Grosso.
Cavalcanti FR, Resende MLV, Carvalho CPS, Silveira JAG, Oliveira JTA (2007) An aqueous suspension of Crinipellis perniciosa mycelium activates tomato defence responses against Xanthomonas vesicatoria. Crop Protection 26:729-738.

Chen C, Bélanger RR, Benhamou N, Paulitz TC (2000) Defense enzymes induced in cucumber roots by treatment with plant growthpromoting rhizobacteria (PGPR) and Pythium aphanidermatum. Physiological and Molecular Plant Pathology 56:13-23.

Colson-Hanks ES, Deverall BJ (2000) Effect of 2,6dichloroisonicotinic acid, its formulation materials and benzothidiazole on systemic resistance to Alternaria leaf spot in cotton. Plant Pathology 49:171-178.

Halfeld-Vieira BA, Vieira Júnior JR, Romeiro RS, Silva HSA, Baracat-Pereira MC (2006) Induction of systemic resistance in tomato by autochthonous phylloplane resident Bacillus cereus. Pesquisa Agropecuária Brasileira 41:1247-1252.

Hoffland E, Hakulinen J, van Pelt JA (1996) Comparison of systemic resistance induced by avirulent and nonpathogenic Pseudomonas species. Phytopathology 86:757-762.

Ishida AKN (2004) Resistência induzida por rizobactérias e acibenzolar-S-metil (ASM) no controle da mancha angular (Xanthomonas axonopodis pv. malvacearum) do algodoeiro. $\mathrm{PhD}$ Thesis. Lavras MG. Universidade Federal de Lavras.

Kado CI, Heskett MG (1970) Selective media for isolation of Agrobacterium, Corynebacterium, Erwinia, Pseudomonas and Xanthomonas. Phytopathology 60:969-976.

Kilic-Ekici O, Yuen GY (2004) Comparison of strains of Lysobacter enzymogenes and PGPR for induction of resistance against Bipolaris sorokiniana in tall fescue. Biological Control 30:446-455.

Lavania M, Chauhan SVS, Singh HB, Nautiyal CS (2006) Induction of plant defense enzymes and phenolics by treatment with plant growth-promoting rhizobacteria Serratia marcescens NBRI1213. Current Microbiology 52:363-368.

Monties B (1989) Lignins. In: Dey PM, Harbone JB (Eds.) Methods in Plant Biochemistry. New York NY. Academic Press. pp. 113158.

Nicholson RL, Hammerschimidt R (1992) Phenolic compounds and their role in disease resistance. Annual Review of Phytopathology 30:369-389. 1992.

Oostendorp M, Kunz W, Dietrich B, Staub T (2001) Induced disease resistance in plants by chemicals. European Journal of Plant Pathology 107:19-28.

Pieterse CMJ, van Pelt JA, van Wees SCM, Ton J, Verhagen BWM, Léon-Lloosterziel K, Hase S, de Vos M, van OostenV, Pozo M, Spoel S, van der Ent S, Koornneef A, van Loon LC (2004) Rhizobacteria-induced systemic resistance and pathway cross talk to fine-tune defense. Anais. II Reunião Brasileira sobre Indução de Resistência em Plantas e IV Simpósio de controle de Doenças de Plantas. Lavras MG. pp. 44-58.

Pieterse CMJ, van Wees, SCM, Hoffland E, van Pelt JA, van Loon LC (1996) Systemic resistance in Arabidopsis induced by biocontrol bacteria is independent of salicylic acid accumulation and pathogenesis-related gene expression. The Plant Cell 8:12251237.

Pieterse CMJ, van Wees SCM, van Pelt JA, Knoster M, Laan R, Gerrits H, Weisbeek PJ, van Loon LC (1998) A novel signaling pathway controlling induced systemic resistance in Arabidopsis. 
The Plant Cell 10:1571-1580.

Ryu CM, Hu CH, Reddy MS, Kloepper JW (2003) Different signaling pathways of induced resistance by rhizobacteria in Arabidopsis thaliana against two pathovars of Pseudomonas syringae. New Phytologist 160:413-420.

Saravanakumar D, Vijayakumar C, Kumar N, Samiyappan R (2007) PGPR-induced defense responses in the tea plant against blister blight disease. Crop Protection 26:556-565.

Shaner G, Finney R (1977) The effect of nitrogen fertilization on the expression of slow-mildewing resistance in Knox Wheat. Phytopathology 67:1051-1056.

Sidhu GS, Webster JM (1977) The use of aminoacid fungal auxotrophs to study the predisposition phenomena in the rootknot: wilt fungus disease complex. Physiological Plant Pathology 11:117-127.

Silva HSA, Romeiro RS, Macagnan D, Halfeld-Vieira BA, Pereira MCB, Mounteer A (2004) Rhizobacterial induction of systemic resistance in tomato plants: non-specific protection and increase in enzyme activities. Biological Control 29:288-295.

Traw MB, Kim J, Enright S, Cipollini DF, Bergelson J (2003) Negative cross-talk between salicylate- and jasmonate mediated pathways in the Wassilewskija ecotype of Arabidopsis thaliana. Molecular Ecology 12:1125-1135.

Urbanek H, Kuzniak-Gebarowska E, Herka H (1991) Elicitation of defense responses in bean leaves by Botrytis cinerea polygalacturonase. Acta Physiologia Plantarum 13:43-50.

van Loon LC (1992) Induced resistance in plants and the role of pathogenesis-related proteins. European Journal of Plant Pathology 103:753-765.

van Loon, L.C., Bakker, P.A.H.M. \& Pieterse, C.M.J. Systemic resistance induced by rhizosphere bacteria. Annual Review of Phytopathology 36:453-483. 1998.

van Wees ACM, Swart EAM, van Pelt JA, van Loon LC, Pieterse CMJ (2000) Enhanced of induced disease resistance by simultaneous activation of salicylate- and jasmonate-dependent defense pathways in Arabidopsis thaliana. Proceedings of the National Academy of Sciences of the USA 97:8711-8716.

Venâncio WS, Zagonel J, Furtado EL, Souza NL, Peres NARP (2000) Novos fungicidas. II - famoxadone e indutores de resistência. Revisão Anual de Patologia de Plantas 8:59-92.

Xue L, Charest PM, Jabaji-Hare SH (1998) Systemic induction of peroxidases, $\beta$-1,3-glucanases, chitinases, and resistance in bean plants by binucleate Rhizoctonia species. Phytopathology 88:359-365.

Received 4 September 2006 - Accepted 12 February 2008 - TPP 6093 Associated Editor: Marisa A.S.V. Ferreira 